Info Artikel:

\title{
Peningkatan motivasi belajar siswa melalui project "globalisasi" dalam pembelajaran IPS
}

\author{
Riza Despita ${ }^{1}$, Maria Montesori ${ }^{2}$ \\ ${ }^{12}$ Program Pasca Sarjana Universitas Negeri Padang
}

\begin{abstract}
This research aims to improve students 'learning motivation on Globalization held at class $I X .7$ MTs $N 1$ Bukittinggi through Learning Project-Based Learning model with the method of efficiency of mapping the Mind. This Research Study shaped the action classes that researchers do two cycles, each cycle four times. Each cycle comprises planning, action, execution, and reflection. The subject of research grade IX. 7 years Lessons 2018/2019. The data source through the student and teacher. The technique of collecting data through observation and question form. Data analysis with descriptive with calculated the percentage. Quantitative data used (assessment of learning results) qualitative data (now motivate learning). The results showed the EXECUTION model using the method of Mind efficiency of mapping content globalization class IX. 7 years 2018/2019 lessons can improve student learning motivation on the cycle, I 80\% increased to $85 \%$ in cycle II. With increasing student learning outcomes learning motivation can also be increased from $50.00 \%$ in cycle, I became $83.33 \%$ in cycle II.
\end{abstract}

Keyword: project based learning (PJBL), mapping the Mind, motivation of learning

This is an open access article distributed under the Creative Commons Attribution License, which permits unrestricted use,
distribution, and reproduction in any medium, provided the original work is properly cited. C2019 by author.

\section{PENDAHULUAN}

Kualitas suatu negara ditentukan oleh sumber daya manusia dan pendidikannya. Peningkatan sumber daya manusia yang berkualitas telah dituangkan dalam pembukaan UUD 1945 dengan tujuan mencerdaskan kehidupan bangsa, maka dari itu dikeluarkannya Undang-Undang yang mengatur tentang Sistem Pendidikan Nasional Nomor 20 tahun 2003. Dalam pembangunan nasional diperlukan bagaimana upaya untuk mencerdaskan kehidupan bangsa. Adapun pembangunan nasional memiliki visi dengan mewujudkan sistem pendidikan sebagai salah satu institusi sosial yang berwibawa dalam pemberdayaan semua masyarakat Indonesia menjadi manusia yang bermutu sehingga dapat aktif bersaing dengan perubahan dan tantangan dari setiap perubahan yang terjadi.

Untuk meningkatkan kualitas pendidikan maka diperlukan pembaharuan untuk menata komponen dalam pendidikan. Diantara komponen tersebut adalah pembaharuan kurikulum, efektifitas pemakaian metode pembelajaran dan peningkatan kualitas pembelajaran. Maka pemerintahpun sudah berupaya merevisi kurikulum sehingga muncullah kurikulum 2013 sebagai penyempurnaan kurikulum sebelumnya yaitu kurikulum tingkat satuan pendidikan (KTSP) yang mulai diterapkan pada Tahun Pelajaran 2014/2015.

Menurut Hamalik (2013) menyatakan bahwa Kurikulum 2013 merupakan suatu upaya bagaimana mempersiapkan generasi untuk menghadapi tantangan masa akan datang. Dalam kurikulum 2013 memiliki tiga kompetensi yang wajib dimiliki siswa yaitu kompetensi pengetahuan, sikap dan keteramplan yang lebih efektif, 
efisien, kreatif dalam menjawab persoalan yang akan dihadapi siswa. Materi dalam pembelajaran IPS pada tingkat sekolah menengah menggunakan pendekatan scientific secara terpadu yang dikembangkan dari fenomena-fenomena sosial yang terjadi dekat dengan lingkungan siswa kemudian meluas pada lingkungan sekolah, masyarakat sekitar tempat tinggal siswa sampai pada wilayah negara bahkan dunia.

Siswa beranggapan bahwa pembelajaran IPS memiliki materi yang sangat banyak, luas dan sangat sulit untuk menghafalnya, sehingga timbullah rasa bosan bagi siswa. Selanjutnya masih terdapat beberapa guru yang belum menyiapkan rencana pembelajaran yang dibutuhkan dalam proses pembelajaran seperti penyiapan materi sesuai dengan tema yang relevan dengan kebutuhan siswa. Guru masih belum terampil menggunakan beberapa model pembelajaran yang dapat merangsang motivasi belajar siswa. Situasi ini dapat mempengaruhi kelancaran dalam proses pembelajaran di kelas sehingga berdampak terhadap kurangnya pemahaman siswa terkait dengan konsep yang disampaikan guru. Maka dari itu supaya materi dalam pembelajaran IPS yang mengandung konsep bersifat abstrak diperlukan model dan metode pembelajaran yang tepat agar siswa lebih mudah memahami konsep yang terkandung didalam materi yang akan dipelajari.

Model pembelajaran PJBL dapat menciptakan suasana yang menyenangkan dalam proses belajar dan membangkitkan motivasi belajar. Kamdi (2007) menyatakan model pembelajaran berbasis proyek merupakan salah satu bentuk pembelajaran yang inovatif, dapat menekankan pada kontekstual dalam kegiatan yang kompleks. Pembelajaran proyek berfokus kepada konsep, prinsip inti dari suatu ilmu yang melibatkan siswa pada pembelajaran investigasi dalam memecahkan masalah yang akhirnya dapat menghasilkan suatu produk yang nyata. Pemanfaatan model pembelajaran yang tepat merupakan salah satu upaya bagai guru untuk mencapai tujuan pembelajaran yang bervariasi sehingga dapat meningkatkan motivasi belajar siswa terhadap pembelajaran IPS.

Motivasi merupakan suatu proses yang bersifat internal mampu mengaktifkan, menuntut dan mempertahankan serta mengaktifkan perilaku siswa. Siswa harus memiliki motivasi belajar yang tinggi karena motivasi memiliki peran penting untuk meningkatkan kualitas pendidikan. Motivasi juga dipandang sebagai dorongan mental yang menggerakkan dan mengarahkan perilaku manusia termasuk perilaku belajar. Menurut Dimyati dan Mudjiono (2006:85) motivasi belajar penting bagi siswa pada awal proses belajar, saat dan setelah belajar dan menginformasikan kekuatan usaha belajar kepada siswa. Djamarah (2008:157) menyatakan motivasi memiliki fungsi sebagai pengaruh perbuatan, penggerak perbuatan dan sebagai pengaruh perbuatan.Dari uraian di atas motivasi merupakan kondisi psikologis yang terdapat dalam diri seseorang yang dapat mendorong seseorang untuk melakukan aktivitas tertentu guna mencapai suatu tujuan.

Berdasarkan analisis hasil belajar diperoleh nilai belajar siswa khususnya IX.7 rendah dibandingkan kelas sembilan yang lainnya. Setelah dilakukan observasi dan wawancara ditemukan juga bahwa motivasi belajar siswa juga rendah. Oleh karena itu perlu adanya upaya untuk mengatasi permasalahan tersebut dengan melaksanakan suatu metode yang sesuai agar motivasi belajar siswa dapat meningkat.

Adapun metode yang digunakan dengan Project Based Learning (PJBL) yang disertai dengan pembuatan Mind Maping sebagai project siswa. Metode project based learning yang digunakan sesuai dengan siswa supaya siswa termotivasi dan terlibat langsung dalam proses pembelajaran proyek mind maping yang digunakan mempermudah siswa untuk memahami materi IPS, karena menurut siswa materi IPS sangatlah sulit bagi mereka untuk menghafal. Melalui penyelesaian proyek mind maping mencakup semua indicator kompetensi yang di proyekkan. Berdasarkan dari beberapa temuan dan fakta tersebut maka peneliti akan mengkaji permasalahan dengan judul Peningkatan Motivasi Belajar Siswa Melalui Project "Globalisasi” Dalam Pembelajaran IPS Kelas IX.7 MTsN 1 Bukittinggi.

\section{METODE}

Rancangan penelitian ini berbentuk Penelitian Tindakan Kelas (PTK), dimana menggunakan pendekatan kualitatif. PTK merupakan penelitian yang dilakukan oleh seorang guru yang berada didalam kelas tempat guru tersebut mengajar melalui refleksi serta bertujuan untuk memperbaiki kinerja guru yang bersangkutan agar jauh lebih meningkat Wardhani (2007). Pendapat yang senada juga disampaikan oleh Amin (2011) bahwa Penelitian Tindakan Kelas merupakan salah satu upaya untuk meningkatkan profesionalisme dan memperbaiki seorang guru dalam proses pembelajaran di dalam kelas dengan melihat keberhasilan dari setiap indikator yang terkait dalam pembelajaran. Penelitian kualitatif dalam penelitian tindakan kelas ini untuk mendeskripsikan persentase perubahan yang terjadi. Penelitian ini dilaksanakan dalam dua siklus yang terdiri dari empat tahap yaitu 
perencanaan, pelaksanaan Kunandar (2011). observasi dan refleksi. Subjek penelitian siswa kelas IX.7 MTsN 1 Bukittinggi Jl. Kusuma Bhakti Gulai Bancah dengan jumlah siswa 38 orang.

Objek penelitian motivasi belajar siswa kelas IX.7. Pengumpulan data diperoleh dari informan melalui dokumen dan kegiatan selama proses pembelajaran melalui pengamatan dan observasi. Adapun teknik dari pengumpulan data penelitian dilakukan dengan observasi dan penyebaran angket kepada siswa. Analisis data dengan deskriptif yaitu melakukan perhitungan persentase. Data yang digunakan berbentuk data kuantitafif yaitu penilaian hasil belajar selama proses belajar mengajar berlangsung serta data kualitatif yang menggambarkan peningkatan motivasi siswa dalam pembelajaran.

\section{HASIL DAN PEMBAHASAN}

\section{Siklus I}

Siklus I terdiri dari empat kali pertemuan, dimana pertemuan pertama sampai ketiga memiliki tagihan dari pertemuan pertama membuat resume, pertemuan ke dua dan ke tiga membuat laporan hasil diskusi serta pertemuan ke empat dengan mid tes. Pada penelitian project based learning ini disertai dengan mind maping. Kegiatan pembelajaran yang dilakukan guru memberikan pengarahan kepada siswa terhadap model pembelajaran yang akan dilaksanakan pada proses belajar mengajar.

Selanjutnya guru melakukan motivasi dengan menyampaikan tujuan pembelajaran. Tahap selanjutnya guru memberikan apersepsi dengan meningkatkan beberapa pertanyaan yang berhubungan dengan materi yang akan diproyekkan yaitu Globalisasi. Pada pertemuan pertama ini guru menyuruh siswa untuk membaca buku sumber yang telah ditetapkan. Setelah itu siswa mulai membuat resume sesuai indikator yang akan dicapai dalam pembelajaran. Guru bersama siswa membuat kesimpulan, guru memberi penguatan materi yang esensial kepada siswa.

Setelah pertemuan pertama selesai dilanjutkan pada pertemuan kedua dan ketiga. Guru melanjutkan kegiatan pembelajaran dengan diskusi kelompok.Pada kegiatan inti guru membagi siswa menjadi enam kelompok yang memiliki anggota berjumlah enam orang secara heterogen. Tahap berikutnya guru memberikan arahan tentang proses belajar mengajar yang akandilaksanakan. Setelah kelompok dibagi siswapun duduk dikelompok masing-masing untuk mendiskusikan jawaban yang telah diresume siswa secara individu dalam kelompok atas pertanyaan yang diberikan. Guru membimbing siswa dalam pelaksanaan diskusi kelompok terhadap pelasanaan diskusi. Angket motivasi dilakukan setiap akhir pertemuan dilaksanakan untuk melihat peningkatan motivasi belajar siswa sesuai indikator motivasi.

Pada akhir siklus dilaksanakan mid tes dalam bentuk pemberian soal essay, dengan pemberian penskoran masing-masing soal berbeda sesuai dengan tingkat kesulitan soal. Hasil siklus I disajikan dalam tabel 1.

Tabel 1. Data motivasi belajar siswa kelas IX.7 Siklus 1

\begin{tabular}{cc}
\hline Pertemuan & Rata-rata \\
\hline I & 77 \\
II & 81 \\
III & 80 \\
IV & 81 \\
Rata-rata & $\mathbf{8 0}$ \\
\hline
\end{tabular}

Rata-rata motivasi belajar siswa siklus I adalah $80 \%$, apabila dikategorikan berdasarkan kriteria motivasi pada rentang $61 \%-80 \%$ adalah tinggi. Hal ini disebabkan karena terlihat pada pengukuran angket siswa sudah mulai memimiliki minat belajar tinggi. Siswa merasa kecewa apabila tertinggal materi pelajaran dari temantemannya. Siswapun mulai berkonsentrasi saat pembelajaran berlangsung.

Selanjutnya siswa kelas IX.7 sudah tidak mudah putus asa hal ini disebabkan siswa merasa senang dengan tugas-tugas yang diberikan guru dan siswapun tidak lagi menyerah dengan tugas yang diberikan guru apabila mereka tidak menjawab tugas tersebut. Siswa juga merasa senang dapat menemukan dan menyelesaikan masalah, sebab mereka menemukan cara yang mudah dalam menghafal materi IPS yang selama ini mereka anggap sangat membosankan. Siswa sudah tidak tergantung lagi dengan orang lain dalam menyelesaikan tugastugas yang diberikan. 
Setelah tindakan siklus I dilaksanakan maka peneliti mengadakan refleksi dengan mengkaji hasil yang telah di analisis, serta mengkaji hal-hal atau masalah-masalah yang timbul selama pelaksanaan siklus I. Dalam pelaksanaan hasil belajar pembuatan resume, diharapkan siswa harus membuatnya sistematis dan hendaknya selalu membuat identitas dari materi apa yang dibahas. Sedangkan dalam pembuatan hasil laporan diskusi kelompok, siswa belum mampu mengambil intisari bacaan sehingga jawaban atau merumuskan jawaban siwa belum tepat.Selain itu siswa juga belum semuanya berpartisipasi aktif dalam berdiskusi dikarenakan tidak semua siswa yang mau membaca sumber-sumber bacaan yang telah ditentukan, tidak maunya siswa dalam kelompok mencocokkan hasil kerja individe atau resumenya dalam diskusi.

Merujuk dari kendala-kendala yang peneliti hadapi selama siklus I, maka peneliti berupaya akan melakukan perbaikan tindakan dengan memotivasi siswa: 1) agar siswa harus percaya diri akan hasil kerja mereka, 2) dalam setiap melakukan pekerjaan harus membuat identitas atau tema, 3) memberikan reword secara verbal bagi siswa yang mengerjakan tugas dengan baik dan sempurna dengan cara bertepuk tangan.

\section{Siklus II}

Berdasarkan hasil refleksi dalam pelaksanaan penelitian tindakan kelas pada siklus I, untuk melihat hasil yang lebih baik maka peneliti melanjutkan siklus II.Hasil penelitian motivasi belajar setiap pertemuan pada siklus II peneliti sajikan dalam tabel 2.

Tabel 2. Data motivasi belajar siswa kelas IX.7 Siklus II

\begin{tabular}{cc}
\hline Pertemuan & Rata-rata \\
\hline 1 & 83 \\
II & 84 \\
III & 86 \\
IV & 87 \\
Rata-rata & $\mathbf{8 5}$ \\
\hline
\end{tabular}

Pada siklus II rata-rata motivasi belajar siswa adalah 85\%, apabila dikategorikan dengan rentangan 81-100 maka motivasi belajar siswa sangat tinggi . Hasil pengukuran motivasi pada siklus II siswa sudah bisa menemukan dan menyelesaikan masalah dalam pembelajaran. Hal ini disebabkan karena siswa yang sudah mulai merasa kecewa apabila mendapatkan nilai atau hasil belajar yang rendah. Siswa yang telah mampu memahami materi pembelajaran peneliti mulai melihat mereka mulai mengajak siswa yang lain untuk mengulang kembali materi yang tidak dipahami. Siswa merasa bersemangat dalam memecahkan materi pelajaran yang sulit.

Selain itu siswa senang bekerja mandiri. Hal ini disebabkan selama siklus II dilaksanakan siswa banyak bekeja secara mandiri karena harus menyelesaikan proyeknya yang akan di persentasekan pada pertemuan ke VII dan VIII. Peneliti pun melihat tidak ada siswa yang main-main saat pembelajaran. Siswapun juga merasa senang disaat peneliti masuk ke kelas dan mereka langsung secara spontan memperlihatkan proyeknya walaupun pembelajaran belum dibuka.

Adapun kualitas peningkatan motivasi belajar siswa dari siklus 1 ke siklus II sebesar 5,00\%. Selanjutnya temuan-temuan selama tindakan siklus II diantaranya: 1) Secara umum pembelajaran menggunakan model PJBL dengan memakai metode Mind Maping berjalan sesuai dengan rancangan pembelajaran yang direncanakan peneliti terlihat dari adanya peningkatan motivasi belajar siswa meningkat sehingga hasil belajar siswapun meningkat, 2) Minat belajar siswa juga mengalami peningkatan, 3) Siswa mulai senang menemukan dan menyelesaikan masalah-masalah yang mereka temukan dalam pembelajaran.

\section{Hasil siklus I dan siklus II}

Penggunaan model PJBL pada penelitian tindakan kelas ini dengan metode mind maping mendorong siswa aktif dalam pembelajaran.Siswa tekun dalam belajar, tidak mudah putus asa, memiliki minat belajar, senang belajar sendiri, mulai telaten dalam mengerjakan tugas, dapat mempertahankakn pendapat serta siswa senang juga menemukan dan menyelesaikan masalah yang dihadapi.

Penerapan model PJBL membuat guru dapat mengelola pembelajaran dengan baik yang melibatkakn siswa dengan proyek berupa pembuatan mind maping dimana guru berperan sebagai fasilitator. Mind Maping digunakan sebagai metode agar siswa mudah menghafal materi IPS. Materi yang diproyekkan adalah "Globalisasi" dengan delapan indikator. Pada penelitian ini hasil belajar siswa dengan mencapai ketuntasan 
belajar di atas kriteria ketuntasan minimal 78 berjumlah 19 orang pada siklus I yaitu 50\%. Dimana siswa kelas IX.7 belum mencapai target ketercapaian yang ditentukan sebesar $80 \%$. Pembelajaran dilanjutkan pada siklus II dengan tujuan agar terjadi peningkatan jumlah ketuntasan belajar siswa.Hasil belajar pada siklus II mengalami peningkatan menjadi 83,33\% yaitu sebanyak 30 siswa mencapai nilai diatas KKM. Selanjutnya motivasi belajar siswa pada siklus I dengan rata-rata 84,50\% meningkat pada siklus II menjadi 89,50\%. Maka dari hasil penelitian tindakan kelas yang dilakukan dinyatakan berkasil, karena semua aspek yang diteliti mencapai target yang ditentukan di atas $80 \%$, sehingga pelaksanaan tindakan hanya sampai siklus II.

Hasil penelitian pada siklus II dinyatakan berhasil. Keberhasilan yang terjadi dari siklus I ke siklus II disebabkan karena proyek yang dituntut kepada siswa berbentuk mind maping dapat dipresentasikan siswa dengan baik. Dengan menggunakan mind maping siswa dapat menguasai materi dengan mudah khususnya pada kompetensi yang diteliti. Pembelajaran yang dilaksanakan pada saat siklus II peneliti tekankan kepada bagaimana siswa dapat mengerjakan serta mmembuat mind maping dengan baik serta mampu mempresentasikan mind maping yang telah dibuat sebagai proyek yang baik. Setelah siswa mampu mempresentasikan di depan kelas, dengan reword yang diberikan kepada siswa, membuat siswa termotivasi untuk belajar.

Dalam penelitian Rezeki (2015) menyebutkan proses pembelajaran yang dilaksanakan berbasis proyek dapat meningkatkan motivasi belajar siswa. Hal ini juga terlihat dari hasil penelitian yang peneliti dilakukan. Meningkatnya motivasi belajar siswa di sebabkan karena siswa juga lebih bertanggung jawab dalam menyelesaikan proyek dan mempresentasikan dengan baik. Siswa tidak hanya dituntut untuk menyelesaikan proyek tetapi siswa langsung dapat berlatih dan belajar secara terus menerus untuk memecahkan masalah yang dihadapi.

Proses pembelajaran dengan model proyek memiliki potensi khusus bagi siswa untuk membangun keterampilan belajar yang dimiliki siswa. Perbedaan dengan penelitian Rezeki (2015) menyatakan penelitian dengan menggunakan PJBL disertai peta konsep dapat meningkatkan prestasi belajar dalam bentuk aspek kognitif, afektif dan psikomotor siswa. Selanjutnya pada jurnal Pohan (2013) menyatakan banyak siswa yang kesulitan memahami konsep dan prinsip pada materi IPS, sehingga perlu pendekatan pembelajaran dengan baik dan benar.Salah satunya dengan menggunakan strategi pembelajaran dengan menggunakan peta konsep.Strategi ini dapat membantu siswa menyajikan pelajaran yang sederhana dengan adanya kata kunci yang menguatkan ingatan siswa menyusun konsep dengan mengaitkan semua fakta yang terjadi.

\section{KESIMPULAN}

Penerapan model Project Based Learning dengan metode mind maping pada materi globalisasi di kelas IX.7 MTsN 1 Bukittinggi tahun pelajaran 2018/2019 dapat meningkatkan motivasi belajar siswa dari $80 \%$ menjadi $85 \%$. Dengan meningkatnya motivasi belajar siswa menyebabkan hasil belajar siswapun juga meningkat dari yang tuntas 19 orang dengan persentase 50,00\% menjadi 30 orang dengan persentase 83,33\%.Dari hasil penelitian yang dilakukan sebanyak dua siklus dinyatakan berhasil karena semua aspek motivasi belajar yang diteliti mengalami peningkatan yang menyebabkan hasil belajar siswa juga meningkat.

\section{UCAPAN TERIMA KASIH}

Penelitian ini dapat dilaksanakan dan diselesaikan dengan baik karena berkat bantuan dari berbagai pihak. Oleh sebab itu peneliti mengucapkan bayak berterima kasih kepada Kepala MTsN 1 Bukittinggi, atas izin yang diberikan kepada saya sebagai peneliti yaitu Ibu Dra. Hj.Eva Anggraini, M.Si. Ibu Nurmailis S.Pd sebagai observer selama PTK ini dilaksanakan serta seluruh siswa kelas IX.7 MTsN 1 Bukittinggi. Ibu Dr. Maria Montesori, M.Ed, M.Si selaku dosen pembimbing yang telah memberi saran kepada peneliti demi kesempurnaan karya ini.

\section{DAFTAR RUJUKAN}

Amin, Moh. (2011). Penelitian Tindakan Kelas. Bandung. Remaja Rosdakarya

Alamsyah. (2000). Motivasi Berprestasi dalam Belajar Mengajar.Jakarta : PT. Gramedia Widasarana Indonesia Arikunto, Suharsimi. (2006). Pengantar Statistik Untuk Penelitian. Jakarta : Rineka Cipta

Arikunto, S., Suhardjono dan Supardi. (2007). Penilaian Tindakan Kelas. Jakarta: Bumi Aksara.

Dimyati dan Mudjiono. (2006). Belajar dan Pembelajaran.Jakarta : Rineka Cipta

Djamarah, Syaiful Bahri \& Aswan Zain. (2013). Strategi Belajar Mengajar. Cet 5. Jakarta: PT. RINEKA CIPTA. 
E. Mulyasa. (2013). Pengembangan dan Implementasi kurikulum 2013. Bandung : PT Remaja Rosdakarya.

Hamalik, Oemar. (2009). Proses Belajar Mengajar. Jakarta : Bumi Aksara.

Hamalik, Oemar. (2013). Dasar-dasar Pengembangan Kurikulum. Bandung : Remaja Rosdakarya.

Hutasuhud, Saidun. (2010). Pekbis Jurnal 2 (1), 196-207.

Kemendikbud. (2012). Dokumen Kurikulum 2013. Jakarta : Direktorat Pendidikan Menengah Umum.

Kunandar. (2010). Langkah Mudah Penelitian Tindakan Kelas Sebagai Pengembangan Profesi Guru. Jakarta: Rajawali Pers.

Mulyoto. (2013). Strategi Pembelajaran di Era Kurikulum 2013. Jakarta : Prestasi Pustaka Raya.

Mulyasa. (2013). Pengembangan dan Implementasi Kurikulum 2013. Bandung : Remaja Rosdakarya Offset.

Purwanto. (2011). Evaluasi Hasil Belajar. Yoyakarta: Pustaka Belajar.

Pohan, L.A. (2013). Jurnal Penelitian Keguruan, 1(1), 67-73.

Rezeki, G.S, Haryono dan Ariani, S.R.D. (2013). Jurnal Pendidikan Kimia, 2(3), 175-181

Rusman. (2011). Model-model Pembelajaran Mengembangkan Profesional Guru. Jakarta: PT Raja Grafindo Persada.

Sardiman, A.M. (2003). Interaksi dan Motivasi Belajar Mengajar. Jakarta : PT. Gaja Grafindo Persada.

Sofan, Amri. (2013). Pengembangan dan Model Pembelajaran Dalam Kurikulum 2013 : Jakarta. Prestasi Pustaka.

Suhardjono.( 2012). Penelitian Tindakan Kelas. Jakarta : bumi Aksara

Sudjana, Nana. (2005). Pembinaan dan Pengembangan Kurikulum di Sekolah. Jakarta : Sinar Baru Algensindo.

Subandijah. (1993). Pengembangan dan Inovasi Kurikulum. Jakarta : PT Raja Grafindo Persada 